\title{
Mutual legal assistance on criminal matters: when theory meets practice - a real story
}

\author{
Amparo Salom Lucas ${ }^{1}$. \\ Maria Isabel Llambés Sánchez ${ }^{2}$
}

Accepted: 16 March 2021 / Published online: 29 March 2021

(C) @ ERA 2021

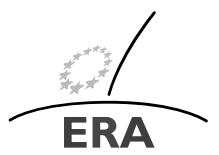

EUROPÄISCHE RECHTSAKADEMIE

ACADEMY OF EUROPEAN LAW ACADEMIE DE DROIT EUROPEEN ACCADEMIA DI DIRITTO EUROPEO TRIER - TREVES - TREVIRI

\begin{abstract}
The instruments of cooperation between different judicial authorities are well known among European judges and prosecutors, and knowledge regarding how they operate has been widely spread via courses and seminars. However, experience shows that judges and prosecutors are reluctant to use them given the practical problems they often entail. The solutions to such problems are not found in the texts of Directives or Conventions, and therefore often, investigating authorities do not know how to proceed in order to be able to conclude an investigation and/or start a trial. This article, by recounting a real experience, illustrates some of the obstacles which are so alien to legislators, and proposes solutions and/or alternatives to speed up requests for assistance.
\end{abstract}

Keywords Judicial cooperation - Mutual assistance · European Arrest Warrant . European Investigation Order · Temporary transfer · Prüm Treaty

\section{The facts}

The time was Autumn 2014. The place was a town in the east of Spain. A man's body was found in a rented apartment by the landlord. The body's hands were tied and he

\footnotetext{
$\triangle$ A. Salom Lucas

a.salom@poderjudicial.es

M.I. Llambés Sánchez

mi.1lambes@poderjudicial.es

1 Judge of Territorial Adscription of the Tribunal Superior de Justicia de la Comunidad Valenciana, Calle Historiador Chabas, 2, CP 46071, Valencia, Spain

2 Senior Judge of Territorial Adscription of the Court of First Instance and Preliminary Investigation No. 4 of Vila-Real, Juzgado de Primera Instancia e Instrucción n ${ }^{\circ} 4$, Calle Matilde Salvador, s/n, CP 12540 Vila-real (Castellón), Spain
} 
was gagged. The homicide brigade of the Civil Guard and the judicial commission (composed of the Judge, the Court Clerk and the Coroner) attended the crime scene. The apparent cause of the death was suffocation caused by a piece of clothing in the victim's mouth, and it was obvious that death had occurred several days ago. Investigators found DNA evidence at the crime scene and the investigation began.

The autopsy confirmed that the victim had died from suffocation, and also that the deceased had walked from his country of origin (France) with some friends days before his death.

\section{The identification of the alleged perpetrators}

After some enquiries, it was possible to identify four male individuals - for the purposes of this article we will refer to them as A, B, C, and D - who were recorded together with the victim by video surveillance cameras of different establishments in the area on dates immediately prior to the murder. Those men had been fully identified in a nearby village by the Civil Police when carrying out a breathalyser test. The occupants of the vehicle concerned (suspects A, B, and D) matched the men recorded by the video surveillance cameras. The vehicle had been identified some minutes after the murder, accessing the AP 7 motorway from the locality where the death occurred. The men had also seen by neighbours alerted by cries for help, coming out of the apartment hastily. In addition, two of them (suspects $C$ and D) were identified by DNA traces and fingerprints found at the crime scene.

From this moment on, the judicial investigation aimed at locating and arresting the suspects. In order to achieve this, several options were considered. One of them was the creation a Joint Investigation Team, (hereinafter 'JIT') with France. Nevertheless, this idea was discarded as issuing European Arrest Warrants, (hereinafter 'EAW') seemed more suitable in this case

The $\mathrm{JIT}^{1}$ is a special investigation tool consisting of the creation of an operative group constituted by authorities from two or more States, in order to carry out a specific criminal investigation in the territory of one or all of each of these States within a fixed period of time. The members of the JIT can exchange information and jointly carry out operations. Furthermore, representatives of EUROJUST, OLAF or EUROPOL may also intervene. The constitution of a JIT can be requested by a Member State or other bodies such as EUROJUST or EUROPOL. The participants in such a team are: the leaders (who direct the research), the members, and participants who are representatives of European bodies such as those already mentioned. On the formation of a JIT, an Operational Action Plan must be drawn up, which is a script of the activity where operational issues are collected.

\footnotetext{
${ }^{1}$ Regulated in the 2000 Convention. For those States that have not ratified the Convention, Council Framework Decision 2002/465, of June 13, 2002 is applicable. In the case of Spain, Joint Investigation Teams are regulated under Act 11/2003 of May 21 and Act 3/2003. EUROPOL publishes a practical guide on its website: https://www.europol.europa.eu/publications-documents/jits-practical-guide.
} 


\section{The European Arrest Warrant and its problems}

Once the suspects were identified, the procedure to locate them was in theory a simple matter, as it would suffice to issue a European Arrest Warrant. The European Arrest Warrant ${ }^{2}$ is a judicial request issued by an EU Member State to obtain the arrest and surrender by another Member State of a person who is wanted so as to be prosecuted or to serve a sentence. The Spanish Act of Mutual Recognition 23/2014 states that a European Arrest Warrant can not be issued for taking a statement, since for this recourse must be had to the ordinary system of legal assistance. In the case of Spain it is also necessary that the crime be punishable by the law of the issuing Member State by a custodial sentence or a detention order for a maximum period of at least twelve months, and that the requirements set out in Spanish Procedural Law regarding the grant of pre-trial custody be met. ${ }^{3}$ If the European Arrest Warrant is issued to enforce a sentence, the conviction must be one of more than four months of deprivation of liberty and the sentence must not have been replaced or suspended.

In Spain, any judge or criminal court, including juvenile judges, may act as an "issuing judicial authority," after hearing the Public Prosecutor and the private accusation, as the case may be. The European Arrest Warrant may only be issued if the prosecution so requests, in the case of the exercise of criminal actions (not the execution of a sentence). For its issuance, the requesting authority must fill out the

\footnotetext{
${ }^{2}$ Framework Decision 2002/584/JHA of the Council, of June 13, 2002, relative to the European Arrest Warrant and the surrender procedures between Member States; Directive 2013/48/EU of the European Parliament and of the Council, of October 22, 2013, on the right of access to a lawyer in criminal proceedings and in European arrest warrant proceedings, and on the right to have a third party informed upon deprivation of liberty and to communicate with third persons and with consular authorities while deprived of liberty; Directive (EU) 2016/1919 of the European Parliament and of the Council of October 26, 2016, on legal aid for suspects and accused persons in criminal proceedings and for requested persons in European arrest warrant proceedings. The Framework Decision was implemented in Spain by Act 3/2003 of March 14, and by Act 23/2014 of November 20.
}

${ }^{3}$ Art. 503 Ley de Enjuiciamiento Criminal (LECRIM):

"1. Provisional detention may only be granted when the following requirements are met:

1. The existence of one or more facts that present the character of a crime punishable by a penalty whose maximum sentence is equal to or greater than two years in prison, or with a deprivation of liberty of lesser duration when the investigated or accused subject has a criminal record not cancelled nor subject to cancellation, derived from a conviction for a malicious crime.

If there are several facts, the provisions of the special rules for the application of penalties will be followed, in accordance with the provisions of Sect. 2 of chapter II of title III of book I of the Penal Code.

2. That sufficient reasons appear in the case to believe the person against whom the arrest warrant is to be issued is criminally responsible for the crime.

3. That by means of provisional imprisonment any of the following purposes is pursued:

a) Ensure the presence of the investigated or accused in the process when a flight risk can be rationally inferred. [...]

b) Avoid the concealment, alteration or destruction of the sources of evidence relevant to the prosecution in cases where there is a well-founded and specific danger.[...]

c) Prevent the person under investigation or the accused from acting against the victim's legal rights, especially when this is one of the persons referred to in Article 173.2 of the Penal Code. In these cases, the limit of the penalty established by ordinal 1 of this section will not be applicable. $[\ldots] "$

https://www.boe.es/buscar/act.php?id=BOE-A-1882-6036\&p=20200930\&tn=1\#a505. 
form that, in the case of Spain, appears in the annex to Act 23/2014, one for each suspect, with the content provided for in Article 36 of aforementioned Act. The use of a single form for all Member States is aimed at enhancing the effectiveness of the warrant, regardless of the EU country where the wanted person is arrested. When the whereabouts of the wanted person are unknown, as was the situation in the case being discussed here, the template is sent to Interpol or SIRENE for entry into the Schengen Information System (SIS).

Nevertheless, practical problems began to appear in our case, of a kind not foreseen either by the Directive or by national law, and which needed to be solved, such as, for example, the issue of which State was responsible for translation, what documentation exactly had to be attached to the order so that it was not rejected, or by what means it should be sent.

Other minor issues that arose, and that jeopardised the success of the European Arrest Warrant, were, for example, communications with the executing judicial authority - calls abroad were simply disabled in every telephone and fax machine at the Spanish court.

It is advisable to have the translation of a European Arrest Warrant prepared in advance, as well as the translation of the accompanying documentation, so that when the arrest occurs, these can be forwarded promptly and within the time limits. Translating documentation once the suspects have been arrested entails risks regarding time and quality, since timeliness and accuracy in the process are essential.

It should be stressed that from our experience it is not enough to fill out and send a European Arrest Warrant template correctly and with all the requirements for it to be successful met. Constant monitoring is also necessary - otherwise the execution of the warrant may be unnecessarily delayed.

In our case, there was no answer from the French authority regarding the European Arrest Warrant, and the solitude of the investigating judge became obvious. So, what was to be done? No alternative remained but to resort to liaison and cooperation tools in order to enquire about the status of the warrants. First, the judge requested the help of the REJUE. ${ }^{4}$ Some judges helped more than others, but no practical information was provided. After this failed attempt, the judge asked for the help of the liaison judge. ${ }^{5}$ During the entire investigation three different liaison judges between Spain and France were appointed, and their attitudes and their level of follow-up varied. In the end, it was EUROJUST ${ }^{6}$ which definitely unblocked the situation, facilitating

\footnotetext{
${ }^{4}$ The REJUE is the Spanish Judicial Network for International Cooperation. The European Judicial Network is constituted by a Secretariat based in The Hague, the European Commission and the contact points of the Member States. It was created by Joint Action 98/428/JHA of June 29, 1998. The contact points are active intermediaries, seeking to facilitate cooperation between the judicial authorities of different States, at the disposal of their corresponding national authority and the rest of the contact points, providing legal and practical information to improve judicial cooperation.

${ }^{5}$ Liaison judges are regulated by Joint Action 96/277/JHA of April 22, 1996, and Joint Action 96/602/JHA of October 14, 1996 and in Spain by Act 16/2015 of July 7. A 'liaison judge' is a judge or official of an EU Member State with experience in judicial cooperation whose task is to promote and accelerate, especially through direct contacts with the authorities of the host State, all kinds of judicial cooperation. Currently Spain has liaison judges in the US, France, Italy, Morocco and the United Kingdom.

${ }^{6}$ EUROJUST is constituted by prosecutors, judges, and/or police officers, temporarily assigned by each Member State to support and strengthen coordination and cooperation between the national authorities in
} 
communication between both countries' authorities, and following up the European Arrest Warrants until they were fully executed. This allows us to reach our first conclusion, which is that to help Member States cooperate, all you need to do is to rely on legal professionals who take a genuine interest in the case, not necessarily those with the highest ranks.

\subsection{The European Arrest Order has been granted. Now, how is the arrested subject brought to Spain?}

Warrants were issued for the arrest and surrender of all the subjects involved, and in the case of B, even before the warrant was executed by France, he voluntarily appeared before the investigating Court in Spain.

The next step was finding out how to enforce the European Arrest Warrant of A and $\mathrm{C}$, once these were granted by the executing judicial authority, since the physical transfer of the detainees was not going to be immediate. The European Arrest Warrant issued by the Spanish authority and the decision of the French authorities effecting surrender were appealed in France. Meanwhile the investigated subjects were released on probation. Again, follow-up by the Spanish judge was necessary for updates on the status of the appeal, and its result. Once the appeal was dismissed, SIRENE transferred suspects A and C by plane to the airport of Madrid-Barajas, where the preliminary hearing under Article 505.6 of the Spanish Procedural Law ${ }^{7}$ took place. The Madrid judge who conducted said hearing remanded both suspects in pre-trial custody, a decision which was later ratified by the investigating judge in charge of the case. It must be borne in mind that in counting the maximum period for which a person can be deprived of liberty, time begins to run from the moment of arrest in the requested country.

\section{When the suspect is a highly dangerous inmate: DNA, temporary transfer and other problems}

Suspect D was serving a prison sentence in France expected to last until 2043, at the time when the European Arrest Warrant was issued. He was classified as an extremely dangerous prisoner, constituting an extreme flight risk, and therefore could not be physically transferred to the requesting State. The European Arrest Warrant was therefore enforced, but the actual surrender was suspended due to the extremely dangerous nature of the prisoner. Thus, a new practical problem arose, which was not

charge of investigating and prosecuting serious crime that affects two or more Member States to be pursued according to common criteria (Art. 85 TFEU). It was created by Decision 2002/197/JHA.

${ }^{7}$ Art. 505.6 LECRIM:

\footnotetext{
"Where the detainee is arraigned before a judge other than the judge or court that heard or shall hear the case, and the detainee cannot be transferred to appear before the judge in charge of the case within 72 hours, the arraignment court will proceed as provided hereinabove. However, once the judge or court in charge of the case receives the proceedings, the investigated or defendant shall appear before said court assisted by his or her lawyer, as soon as possible and a decision shall be made."
} 
provided for in the written legal protocols, and which the investigating judge faced with no tools other than the law and her imagination.

As part of the investigation stage it was necessary to comply with Article 25 of the Spanish Jury Act, ${ }^{8}$ which basically consists of formally communicating the suspect, assisted by a lawyer, the content of the criminal complaint for which he is being investigated and the charges he is facing. In this case, the judge considered that, given the peculiarities of the case, using videoconferencing was a good solution, given that all the parties would be at the Spanish court, except for the accused who would be in a French prison.

It seemed a suitable decision given the circumstances of the case, since the defendant could not be physically transferred to Spain. Although his rights were respected, and the procedure complied with Spanish procedural law, the prosecutor appealed this decision, preventing the advance of the investigation until the appeal was solved by the second instance Court. The appeal was dismissed and the decision to hold the appearance by videoconference upheld.

It must be recalled that it was the 2000 Convention that introduced the regulation of videoconference hearings (under Article 10.9 thereof $^{9}$ ), because of the limitations of the face-to-face system which had been provided for in the 1959 Convention and for the sake of modernising judicial assistance. Hearing by videoconference is applicable in principle only to witnesses and experts (under Art. 10.1 of the 2000 Convention), although it is possible for there to be hearings involving an accused person as long as there is agreement between the judicial authorities - which was the case here. It is also necessary to have the consent of the accused. The possibility of hearing the person under investigation by videoconference is also covered by Article 24.1 of $\mathrm{Di}$ rective 2014/41/EU of the European Parliament and of the Council of April 3, 2014 on the European Investigation Order in Criminal Matters, ${ }^{10}$ and in Spanish statutory

\footnotetext{
${ }^{8}$ Art. 25.1 Law of the Jury:
}

"1. Once the proceedings for a crime are initiated, the prosecution of which is attributed to the Jury Court, the Investigating Judge will immediately inform the accused. To specify the charges by which the investigation has been initiated, the judge will summon the accused within five days, as well as the Public Prosecutor and any other parties. At the time of the summons, the defendants will be notified of the complaint, if this was not done previously. The accused will necessarily be assisted by a lawyer of his or her choice or otherwise he or she will be defended by a public counsel [... ]"

\title{
${ }^{9}$ Art. 10.92000 Convention:
}

\begin{abstract}
"Member States may at their discretion also apply the provisions of this Article, where appropriate and with the agreement of their competent judicial authorities, to hearings by videoconference involving an accused person. In this case, the decision to hold the videoconference, and the manner in which the videoconference shall be carried out, shall be subject to agreement between the Member States concerned, in accordance with their national law and relevant international instruments, including the 1950 European Convention for the Protection of Human Rights and Fundamental Freedoms. Any Member State may, when giving its notification pursuant to Article 27(2), declare that it will not apply the first subparagraph. Such a declaration may be withdrawn at any time. Hearings shall only be carried out with the consent of the accused person. Such rules as may prove to be necessary, with a view to the protection of the rights of accused persons, shall be adopted by the Council in a legally binding instrument."
\end{abstract}

${ }^{10}$ Art. 24.1 Directive 2014/41: 
law, in Article 197 of Act 23/2014 of 20 November on Mutual Recognition of Judicial Resolutions in the European Union.

In any case, the absence of an express provision in the Conventions, applicable to both States, would not have prevented a hearing by videoconference. This kind of hearing is allowed, for example, by the principle of reciprocity, by the general residual clause setting out a commitment to provide legal assistance in the broadest terms of the Conventions in general (and in particular in Art. 1.1 of the 1959 Convention), plus the fact that it is not prohibited either by the Schengen Convention or by the 1959 Convention, so that it will depend on the interpretation of the internal legislation in conjunction with the Conventions by the authorities of the requested State.

On a practical note, it is worth highlighting that the summoning of the person to be heard corresponds to the requested State, that the judicial authority of the requested State must be present during the declaration and identification of the person to be heard, thus guaranteeing respect for his or her rights, and that the costs of the hearing have to be refunded by the requesting State to the requested State, unless the latter, at its discretion, waives said reimbursement in whole or in part.

Once all the above was dealt with in the case under discussion, we came across the next stumbling block: the physical materialisation of the videoconference with the French penitentiary. For this, a letter rogatory was sent, ${ }^{11}$ which was neither completed nor answered. Finally, the practical solution was to make a telephone call from the Spanish judge to the prison director with the help of a French interpreter, once the telephone was enabled for calls to France. Through this telephone conversation, it was possible to arrange an appointment to carry out the hearings (declaration as subject of an investigation and hearing under Article 25 of the Spanish Jury Act). To provide legal coverage, and already knowing the day and the hour on which the videoconference would take place, a new letter rogatory was sent to the prison containing this data. In addition, Spanish videoconference systems often fail, depending on the territory where the Courts are located because of software incompatibilities, as the competencies for the development of IT systems lie with different authorities. Anticipating a problem, this circumstance was brought to the attention of the competent authority for the management of computer systems who opened a "direct communication channel" between both institutions (the Spanish Court and the French prison), which was also used for the lawyer to meet with his client.

Returning to our case, let us recall that we have previously said that untraceable biological material had been collected at the crime scene, and that its result was compared with the national and international registries approved by the Prüm Treaty in terms of DNA, giving a coincident result with two genetic profiles that appeared in the French registries corresponding to the investigated subjects $\mathrm{C}$ and $\mathrm{D}$.

\footnotetext{
"Where a person is in the territory of the executing State and has to be heard as a witness or expert by the competent authorities of the issuing State, the issuing authority may issue an EIO in order to hear the witness or expert by videoconference or other audiovisual transmission in accordance with paragraphs 5 to 7 .

The issuing authority may also issue an EIO for the purpose of hearing a suspected or accused person by videoconference or other audiovisual transmission."
}

${ }^{11}$ At that time, Directive 2014/41/EU of the European Parliament and of the Council of April 3, 2014 on the European Investigation Order had not yet been transposed into the Spanish legal system. 
The Prüm Treaty of May 27, 2005 was created with the purpose of intensifying cooperation between Member States in the fight against terrorism, cross-border crime and illegal migration. The decisive importance of this agreement lies in the creation of three types of national files related to DNA profiles, fingerprint and vehicle data.

The Hague Programme defines the principle of availability, ${ }^{12}$ and specifies the minimum requirements for the application of the principle:

- the exchange may only take place in order that diligence of investigation provided by law may be performed;

- the integrity of the data that is to be exchanged must be guaranteed;

- sources of information must be protected and data confidentiality secured at all stages of the exchange;

- common standards for access to the data and common technical standards must be applied;

- supervision of data protection, and appropriate control prior to and after the exchange must be ensured;

- individuals must be protected from the abuse of data and have the right to seek the correction of incorrect data.

Focusing on DNA profiles, the Prüm Treaty creates national files for the prosecution of crime and not for preventive purposes.

In order to carry out an automated consultation and comparison between the different databases of the Member States, that is, a cross-border match, it is necessary to use the communication network of the Trans-European Services for Telematics between Administrations (TESTA II) and the networks that are subsequently developed from them, in accordance with the provisions of Art. 4 of Decision 2008/616/JHA.

In the case of Spain, the national contact point (NCP), to which Art. 6 of Decision 200/615/JHA refers, is the General Sub-Directorate of Information Systems and Communications for Security of the Secretary of State for Security of the Ministry of the Interior.

Strictly speaking, an automated search in the Prüm framework is divided into two phases: "Step I" consists of the search or comparison of profiles (without associated personal data), which is based on the responses "HIT / NO HIT". If a HIT is obtained, that is, a match of genetic profiles, it must be validated by the laboratory that has the analytical information, and that same laboratory must initiate the second phase, "Step II", which consists in exchanging the personal data associated with the genetic profile in question.

\footnotetext{
${ }^{12}$ This Treaty is intended to consolidate a European area of freedom, security and justice through the socalled "principle of availability" defined in the Program of The Hague 2005/2009 (Communication from the Commission to the Council and the European Parliament, of 10 May 2005, "The Hague Programme: Ten priorities for the next five years. An association for the European renewal in the field of freedom, security and justice" - Official Gazette C 236 of 24 September 2005). This envisages, throughout the territory of the European Union, a police officer of a Member State seeking information in the course of an investigation from another Member State, and that the police body of the other Member State that possesses said information will provide it for the stated purpose. In addition to the Prüm Treaty, the principle of availability was incorporated into European law with JHA Decision 615/2008 of 23 June and Framework Decision 2006/960/JHA of 18 December (known as the "Swedish Initiative").
} 
To carry out "Step I" it is only necessary to seek the approval of the Commission (after the appropriate evaluation) agreeing that the country meets the conditions required in order to carry out the exchange (consisting, fundamentally, of legislation in personal data protection matters, but also of other aspects, such as technical infrastructure, evaluation visits, pilot tests, etc.)

To carry out "Step II", the provisions of Art. 5 of Decision 2008/615/JHA must be met, meaning that once a profile match has been verified, "the supply of any available further personal data and other information relating to the reference data shall be governed by the national law, including the legal assistance rules, of the requested Contracting Party."

In addition, Article 7 of Decision 2008/615/JHA regulates a different issue, that is, the transnational collection of genetic material and transmission of DNA profiles: "where, in ongoing investigations or criminal proceedings, there is no DNA profile available for a particular individual present within a requested Contracting Party's territory, the requested Contracting Party shall provide legal assistance by collecting and examining cellular material from that individual and by supplying the DNA profile obtained." This provision is subject to compliance with the following requirements listed in the Article:

- that the requesting Member State communicate the purpose for which it is required;

- that the requesting Member State produce an investigation warrant or statement from the competent authority, enforceable in accordance with its national law, from which it appears that the requirements for collecting and examining the cellular material would be met if that specific person were to be found in the territory of the requesting Member State, and

- that the requirements for collecting and examining genetic material and for transmitting the DNA profile obtained in accordance with the law of the requested Member State be met. ${ }^{13}$

If a match is ascertained between the profile transmitted and that stored in the file of the requested party, the national point of the requesting State automatically receives information about the existence of the match and its reference. Likewise, the absence of matches is also reported. These files also allow the automated comparison of DNA profiles of their "untraceables" with all the profiles contained in the reference indexes of the other national files, in order to reduce the number of "untraceables." Therefore, if a match of an open fingerprint is found, it should be communicated immediately to the national contact point of the other Party.

Returning to our case, a European Investigation Order for the taking of cellular material of $\mathrm{C}$ and $\mathrm{D}$ was issued to the competent French authority. D who, as we have already noted, was in prison in France for other reasons, did not consent to the collection of DNA samples whilst $\mathrm{C}$ did consent. The principle of locus regit actum ${ }^{14}$ applies in this case that is, French law. This provided that if an investigated person

\footnotetext{
${ }^{13}$ This is detailed verbatim in the judgment delivered by the Provincial Court of Cádiz of March 2, $2018 \mathrm{n}^{\circ}$ 49/2018, Reporting judge Ms. Estrella Ruiz, in relation to fingerprints registered in Finland. ECLI:ES:APCA:2018:400.
}

${ }^{14}$ Article 4 of the 2000 Convention on Judicial Assistance in Criminal Matters. 
did not give consent to give cellular material, it could not be ordered by a judge, as was possible in Spain. ${ }^{15}$

The Spanish judge considered that even without this cellular material the investigation was concluded, because the participation of the investigated subjects $C$ and D was proven by the match of the DNA traces found at the crime scene with the Prüm files of France. Textually the judge argued:

"France turns out to be one of the European countries that routinely exchange genetic profiles with Spain and thus, so that all countries have the assurance that the forensic laboratories of all the Member States are reliable and technically competent and that the genetic profiles stored in the database comply with the same safety requirements as their own laboratories, the Decision of the Council of the European Union establishes the obligation for all these forensic laboratories to be accredited in accordance with the provisions of the UNEEN/ISO/IEC 17025, being, therefore, perfectly homologated registries and that grant a full guarantee of the security and reliability of the data and profiles contained therein."

Nevertheless, the prosecutor also appealed this decision, considering that collecting the cellular material of D was essential. On this occasion the Second Instance Court quashed the decision of the investigating judge and ordered the collection of the DNA material of D because, in the opinion of the Court of Appeal, the collection of the DNA material carried out by the French authority was not made with all the guarantees required by the Spanish Supreme Court. However, the Court of Appeal itself admitted that jurisprudence on this matter was not uniform.

On this issue we should not fail to mention recent decisions of the Spanish Supreme Court such as no. 175/2018 of April 12, which recognises the full validity of the DNA evidence collected by other Member States, in this case, also France, or judgments 456/2013 of June 9, 259/2005 of March 4, 480/2009 of May 22 and $477 / 2013$ of October 8.

This decision had obvious practical difficulties, probably not foreseen by the Second Instance Court itself, being that the locus regit actum was applicable to the case, but the law prohibiting the collection of DNA material when not consented to by the investigated subject... So how could the Second Instance Court decision be enforced? Once again, the law and the good work and imagination of the investigating judge solved the situation. The judge issued a European Investigation Order for the temporary transfer of D to Spain, to collect his cellular material with prior judicial authorisation.

The European Investigation Order (hereinafter EIO) is a judicial decision issued or validated by an authority of a Member State to carry out one or more investiga-

\footnotetext{
${ }^{15}$ Article 363 LECRIM:
}

"The Courts will order the practice of chemical analytics only in cases where they are considered absolutely essential for the judicial investigation and the proper administration of justice.

Provided there are proven reasons that justify this, the Investigating Judge may agree, in a reasoned resolution, to obtain biological samples from the suspect that are essential for the determination of his or her DNA profile. Consequently, the judge may decide to practise those acts of inspection, recognition or bodily intervention that are appropriate to the principles of proportionality and reasonableness." 
tive measures in another Member State to obtain evidence. It is regulated in Directive 2014/41/EU of the European Parliament and of the Council of April 3, 2014, and transposed into Spanish law in Articles 186-223 of Act 23/2014. This law must be interpreted in accordance with the Framework Decision and the jurisprudential criteria of the Court of Justice in Luxembourg, especially the judgment handed down in the Pupino. ${ }^{16}$

At this point a new problem arose in the investigation, related to translation. The Spanish LRM uses two very similar terms to refer to:

- the temporary surrender of the defendant (Art. 43) for the exercise of criminal actions including attending the trial, which is done via European Arrest Warrant, and

- the temporary transfer of the defendant when he or she is in custody in the requested State, which is done via EIO (Art. 195 et seq.) for the practice of diligence of investigation but not to attend trial.

When translating the EIO in our case, the translator confused the terms, fortunately EUROJUST realised in time and we could correct it before sending the request. Had the OEI been submitted in the wrong terms, it would have been rejected, which would have resulted in yet more delay in the investigation.

Again, it took very long to execute the EIO, so constant monitoring was necessary, once the authority to complete it had been ascertained. The Spanish member of EUROJUST supervised the content of the request for assistance and provided contact with the prosecutor in charge of executing the Order, who also spoke Spanish, which greatly facilitated communication.

The investigated subject D consented to be transferred to Spanish territory for the practice of the investigative measure, but he had cases pending with different French courts, so authorisation had to be obtained from all the authorities for the temporary transfer, which all the authorities gave, except for one. Consequently, the

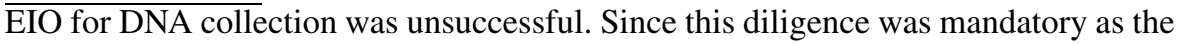
Second Instance Court had ordered it, a new EIO was issued, this time to proceed to the surrender of D to Spain, in order to take the DNA material. The coordination for the surrender was possible thanks to the direct communication with the head of the European Arrest Warrant group at SIRENE, given that multiple unexpected events arose. The intervention of the liaison judge in France was also vital since he dealt with the French authorities and was in coordination with the Spanish judge.

As a consequence of all the foregoing, we can draw the conclusion that, when it comes to criminal cooperation, one must be extremely cautious with language matters, since confusing one single word (as can happen with arrest warrants and/or temporary transfer) can mean the failure of a request for cooperation.

Given D's extremely-dangerous-prisoner status, and the fact that he had refused the collection of DNA material in France but did not object to having it collected in Spain, the suspicion arose that he might organise a breakout taking advantage of this temporary transfer. Given that the procedure involved simply the extraction of cellular material and that the presence of the suspect before the investigating authority was

${ }^{16}$ Case C-105/03 of June 16, 2005 EU:C: 2005:386. 
not necessary, and in order to avoid a long journey that could make it easier for the said subject to flee, it was decided to transfer him by plane to a Spanish military base, since a land transfer was more vulnerable to an attack with the purpose of fleeing. However, and despite the fact that the authorities were willing to assume the high cost of this operation (amounting to between 150,000 and 200,000 euro), D was transferred to another prison for a short trial, and since the deadline to carry out the diligence would soon end, it was necessary to opt for the land route which had previously been discarded. In the end, such measures took place with all legal guarantees, with the assistance of legal counsel and of an interpreter, in the Police Coordination and Customs Headquarters that was closest to the French border in Spanish territory

After this difficult journey, the biological report corroborated the data already available in the case. Once the investigation concluded, the order to begin the trial was issued, an order which according to Spanish legislation had to be notified personally to the accused. The situation became a little more complicated with the months of confinement due to COVID-19 pandemic that ensued. A European Investigation Order was issued for the notification, subpoena, and hearing by videoconference with the French prison. The hearing took place with the assistance of a French interpreter, and previously the translated documents were sent by email. All those legal procedures were carried out with great time pressure since the time limits for pre-trial custody were coming to an end.

The investigation was concluded in spring 2020.

\section{Conclusions}

It is advisable to pay close attention and to be very precise with the translation of legal terms, because a simple mistake can ruin months of investigation and return it to square one.

The writers would recommend centralising in a single body and/or telephone number all the services for the consultation of judges and prosecutors on judicial cooperation, so as to avoid a scattering of services that significantly hinders the provision of adequate information.

In the current state of implementation of the European arrest warrants and European investigation orders, it is not enough to issue warrants correctly. It is necessary to continuously monitor and advance them through direct contact with the authorities and/or persons responsible for their execution. It would be interesting to create a commission to follow up requests for assistance so as to assist the judge or prosecutor with practical problems.

Publisher's Note Springer Nature remains neutral with regard to jurisdictional claims in published maps and institutional affiliations.

\section{References}

1. Carmona Ruano, M., GonzÁLez Vega, I.U., Moreno Catena, V.: (Directors) Cooperación Judicial Penal en Europa. Dykinson Editors (2013). Electronic version available at http://hdl.handle.net/10016/18330 
2. Estévez Mendoza, L.M.: Tratado de Derecho y Políticas de la Unión Europea (Volume VIII) Aranzadi Editors, SA (2016)

3. Fernandez Prado, M.F.: La cooperación judicial penal en Europa: De la asistencia judicial al reconocimiento mutuo Capítulo V. Orden de detención europea, (2018) Editor: Consejo General del Poder Judicial (Madrid)

4. García-Chamón Cervera, E: (director) La aplicación del Derecho de la Unión Europea por el juez español. Una aproximación multidisciplinar (2018) Editor: Consejo General del Poder Judicial (Madrid)

5. Palomo Del Arco, A., Gonzalez Vega, I.U.: La cooperación judicial penal en Europa: De la asistencia judicial al reconocimiento mutuo, Capítulo I. Introducción a la cooperación judicial penal en Europa, (2018) Editor: Consejo General del Poder Judicial (Madrid)

6. Poza Cisneros, M.: La cooperación judicial penal en Europa: De la asistencia judicial al reconocimiento mutuo, Capítulo II. Asistencia judicial mutua (I). Declaraciones: en especial, la videoconferencia. Notificaciones y peticiones de información (2018) Editor: Consejo General del Poder Judicial (Madrid)

7. Sanchez Siscart, J.M.: La cooperación judicial penal en Europa: De la asistencia judicial al reconocimiento mutuo, Anexo: Herramientas técnicas de cooperación judicial penal, (2018) Editor: Consejo General del Poder Judicial (Madrid) 